\title{
The eXe Learning as a solution to the problem of the three phenomena of chemistry learning stages : A Literature Review
}

\author{
Dominikus Djago Djoa ${ }^{1}$, Sunyono ${ }^{2}$, Albet Maydiantoro ${ }^{3}$, Tubagus Ali Rachman Puja Kesuma ${ }^{4}$ \\ Lampung University, \\ J1. Prof. Dr. Soemantri Brojonegoro No. 1 Bandar Lampung, 35141 \\ Indonesia
}

Received: June 10, 2021. Revised: July 14, 2021. Accepted: July 16, 2021. Published: July 20, 2021.

\begin{abstract}
This research is a literature review study that aims to provide understanding and enlightenment to teachers about the feasibility, effectiveness, and usefulness of eXe Learning media as chemistry learning media involving three levels of chemical phenomena: macroscopic, submicroscopic, and symbolic and the practicality of their use in the era of the industrial revolution 4.0 and the Covid-19pandemic. The sources of literature are the articles from the journal Education Resources Information Center (ERIC), Elsevier, and Google Scholar, and it is limited to empirical studies published during the period 2010 to 2020 , and searches using keywords: online learning media, interactive multimedia, online teaching-learning, mobile learning, and eXe Learning media. Of the 25 articles obtained through the above database search, 7 articles were finally selected based on inclusion criteria and analyzed. The results of this study indicate that the eXe Learning media is feasible and effective to be used as ICT-based chemistry learning media because it can improve student learning outcomes, ease of use, ease of learning, student satisfaction, able to improve students' understanding and critical thinking attitude, as well as easy and practical to be used as chemistry learning media involving three levels of chemical phenomena in the era of the Covid19pandemics.
\end{abstract}

Keywords - industrial revolution 4.0, eXe Learning, pandemic Covid-19, chemical phenomenon phenomena

\section{INTRODUCTION}

$\mathrm{C}$ ountries throughout the world are undergoing a transition process towards a digital economy and society in the era of the industrial revolution 4.0 [1]. In the digitalization era, teachers experienced a new challenge, namely the readiness of teachers to anticipate technology, where students can easily access information and knowledge through available technological tools [2] presented a new pedagogy that online learning. Learning is a transformationrelated education sector pandemic Covid-19[3]. Teachers were desirable to use learning media information and communication technologies, to support virtual learning during the Covid-19 pandemic.

Implementation of chemical learning requires teachers to be able to change the way of learning by utilizing information and communication technology in the future, further in pandemics Covid-19 [4] [5].

Chemical learning requires an ICT base because it has many material phenomena that are abstract and difficult to understand by students. There are three levels of chemical phenomena in chemistry learning, namely macroscopic, submicroscopic, and symbolic. It is beneficial to simplify and classify the level of student understanding in learning abstract chemistry concepts [6] [7].

Students often found themselves in misunderstandings in comprehending the chemistry subject through teaching and learning activities both offline and furthermore on online learning [8], [9]. This condition needs to be realized by chemistry teachers so as to improve their students' comprehension and abilities of Chemistry by utilizing digital technology in the field of education as the development transformation of learning in the industrial revolution 4.0 eras.

This change is very influential on changes in the way students learn more dominantly using gadgets both online and offline. Therefore, teachers need to develop learning strategies that are by the times by utilizing teaching media based on information and communication technology in teaching and learning activities [10].

The use of technology in chemistry learning is desirable to support the change of conventional learning systems into 
independent learning that accessible anytime and anywhere. So the independent learning will be easier for students to understand and remember. The research result [11] recommended 29 web- and ICT-based learning media tools for teachers, including eXe (eLearning XHTML editor) learning media.

The eXe Learning is a web-based writing program that can be accessed by teachers and academics to develop learning materials without having expertise in programming languages [12] [13]. The portability of this tool is extreme because it does not require software installation, as it can be used by other software such as USB or other devices [14] [15]. Teachers can develop learning content in a node structure connected by sections and subsections with eXe Learning [16]. Download the eXe Learning at http://eXelearning.org. It is free because it is open-source software, and can be downloaded through windows, Linux, and Macintosh. The content contained in eXe Learning media can be exported to various platforms, including LMS and MOODLE, and is easy to store on a computer and several other media such as android and this media provides tools for virtual learning [17] [18] [19].

We found the advantages of using EXe Learning in some disciplines. In psychology, eXe Learning is used as a medium that helps students to develop self-control skills (selfregulation) in distance learning [20]. In health education, eXe Learning media is used as a medium that can integrate learning objects through object design to build knowledge, skills, attitudes, and teach healthy lifestyles, through audio and video to facilitate understanding of learning topics [21]. This is supported by a statement [22] that explains the use of eXe Learning media as a learning object for nursing students; it can make it easier for them to understand knowledge about the measure of central tendency. In the field of mathematics education, eXe Learning media is used to assist students in doing practice questions and applied mathematics assignments, so that students are easily directed to understand learning content through the choice of question forms in the eXe Learning menu, including through accessing web pages, completing fields and provide problems and methods of solving them [23]. The use of eXe Learning media in learning mathematics shows better student learning outcomes compared to learning without using eXe Learning because through eXe Learning there are various possibilities in making strategies through the very flexible iDevice menu [24].

Therefore, we can say that the EXe Learning can enable students to interact with other students through interactive discussions and questions and answers, as well as convey their ideas, thereby inspiring students who are less active [25].

Various studies to facilitate students' understanding of learning materials and learning outcomes using eXe Learning media have been carried out, including the development of e- chemistry modules on the reaction rate material [26], the development of problem-based learning eXe Learning media for mathematics subjects [27], overcome the problem of learning statistics for high school students in Costa Rica [14], an additional source in the teaching and learning process of physics, the ideal gas sub-topic [28], increasing students' learning motivation through eXe Learning based on Attention, Confidence, Relevance, Satisfaction [29], development of and a comparison of mobile learning in mathematics learning [30], a scientific approach to social arithmetic learning [31]. The studies mentioned above put more emphasis on the application of teaching materials, media, learning outcomes, and certain learning models. In another study, it was said that the problem faced in the era of industrial 4.0 furthermore in the Covid-19 pandemic was the abilities and knowledge of teachers could utilize ICT-based learning media. So, it was recommended that teachers use a platform that can be accessed and used easily, namely eXe Learning [32].

Based on the descriptions and explanations above, the authors conducted a literature review to provide solutions related to the difficulties in learning chemistry, namely providing an explanation of the features and functions of the menus in the eXe Learning media. This is related to the study of chemistry which is abstract and has three levels of chemical phenomena [33].

Several studies have been carried out to solve the problem of student and teacher difficulties related to understanding chemistry learning involving three levels of chemical phenomena, namely macroscopic, submicroscopic, and symbolic [34] [35] [36], but not many studies have used eXe Learning media as supporting media. Chemistry learning activities, which allow contextualization, observation, reflection, synthesis, and interdisciplinary and are able to support the development of critical thinking, involving three levels of chemical phenomena.

Through this literature review, authors want to provide understanding to chemistry teachers and lecturers to increase knowledge about the use of eXe Learning media as a chemistry learning medium, which can be integrated with other chemistry learning models, so as to increase students' understanding of the subject matter. The Chemistry subject is considered difficult. Therefore, the research questions are (a) whether eXe Learning media is feasible and effective to be used as a chemistry learning medium involving three levels of chemical phenomena, and (b) whether eXe Learning media is practically used in the era of the industrial revolution 4.0 and the era of the Covid-19 pandemic.

\section{Method}

This study is a qualitative research using synthetic research methods [37], with the aim of combining empirical studies in the article to generalize. Then perform an analysis to identify 
relevant research using the stages of the process according to Creswell. Data analysis uses six stages, including: data collection, transcripts, reading, coding, interpretation and validation of data accuracy [38].

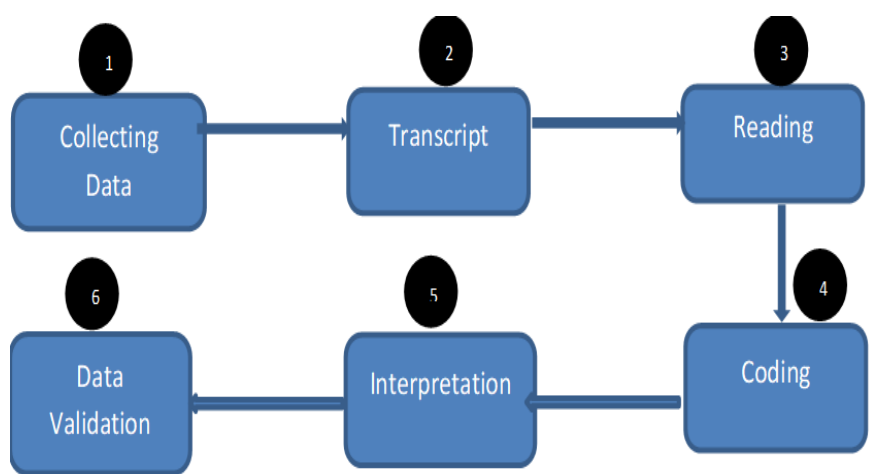

Figure 1 Qualitative Data Analysis Process (adopted from Creswell, 2012)

\section{The first step: Searching for Articles, Processing Transcripts, and Reading Articles}

Literature in the form of articles from journals published from 2010 to 2020, obtained from the journal Education Resources Information Center (ERIC), Elsevier and Google Scholar, and searches using keywords: online learning media, interactive multimedia, online teaching learning, mobile learning, and eXe Learning media.

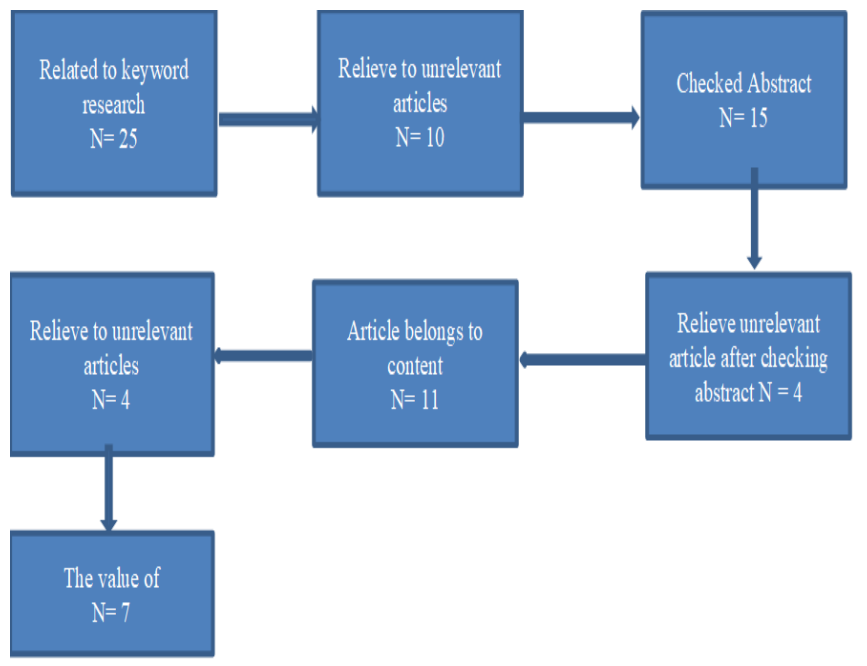

Figure 2 the Process of Selecting, Analyzing and Grouping Articles

\section{Second step: Coding and Interpreting Articles}

One way in qualitative research that uses synthetic research methods is to code it to find a model framework [39]. The screening process in selecting the articles above used the CASP (Critical Appraisal Skill Program) program, with 10 questions to determine accuracy, validity, and usefulness in research. According to Mohamadian et al. [40] the questions were about research objectives, methodological logic, research design, sampling methods, data collection, reflectivity, ethical considerations, accuracy in data analysis, clear disclosure of findings, and research value. The filtering results were further categorized with good scores, namely $31-40$ and very good scores $41-50$ (range value of 50).

After going through the specified stages, we got 7 inclusion articles for review, as shown in Table 1 below..

Table 1 The Articles Review

\begin{tabular}{|c|l|c|}
\hline $\begin{array}{c}\text { Article } \\
\text { code }\end{array}$ & \multicolumn{1}{|c|}{ Authors } & Year \\
\hline 1 & Silalahi M. V & 2020 \\
2 & Prasetyani, Darojah, Novianti, \& & 2019 \\
& Sulisworo & \\
3 & Navarro, Delgado, \& Calderon & 2019 \\
4 & Bulegon \& Tarouco & 2015 \\
5 & Mussoi, Flores, Bulegon, \& Tarouco & 2010 \\
& Yunianta, Putri, \& Kusuma & \\
6 & Rokhima, Harisna, Ningrum, \& & 2019 \\
7 & Sulisworo & 2019 \\
\hline
\end{tabular}

\section{Third step: Article Validation}

Furthermore, the article validation process is carried out based on the results of the coding that has been done [39]. This aims to maintain the quality of this research, as well as to ensure that the coding steps are correct, based on the index of questions about: research objectives, methodological logic, research design, sampling methods, data collection, reflectivity, consideration of ethical factors, accuracy in data analysis., clear disclosure of findings, and research value [40].

\section{RESULT AND DISCUSSION}

Based on the results of data analysis in the articles above, we summarize them by making comparisons to be able to make a concept map by examining all article codes that are similar to one another, so that category classification and studies are obtained, including media feasibility, media effectiveness, and the media use of each article made.

Table 2 Concept Map of Thematic Category Classification from Coding of Article Sources

\begin{tabular}{|c|c|c|}
\hline Factor & Category & $\begin{array}{c}\text { Article } \\
\text { Code }\end{array}$ \\
\hline Media Design & $\begin{array}{c}\text { Validity and feasibility of } \\
\text { eXe Learning media }\end{array}$ & $\begin{array}{c}1,2,3, \\
4,5,6,7\end{array}$ \\
& Students' responses & $1,2,3,4$, \\
$5,6,7$
\end{tabular}




\begin{tabular}{|c|c|c|}
\hline Factor & Category & $\begin{array}{c}\text { Article } \\
\text { Code }\end{array}$ \\
\hline & College & 1 \\
\hline $\begin{array}{c}\text { Effectiveness } \\
\text { media }\end{array}$ & $\begin{array}{c}\text { Increasing Students } \\
\text { Achievement }\end{array}$ & $\begin{array}{c}1,2,3,4, \\
5,6,7\end{array}$ \\
\hline $\begin{array}{c}\text { Utilization of eXe } \\
\text { Learning Media }\end{array}$ & $\begin{array}{c}\text { Facilitate students' } \\
\text { understanding of } \\
\text { learning materials }\end{array}$ & $\begin{array}{c}1,2,3,4, \\
5,6,7\end{array}$ \\
& $\begin{array}{c}\text { Assisting teachers in the } \\
\text { development of ICT- } \\
\text { based media }\end{array}$ & 4 \\
& Self-study & $2,6,7$ \\
\hline
\end{tabular}

The creation and development of eXe Learning media using open source web applications makes it easier for educators and developers to design eXe Learning media constructs.

\section{A. Eligibility of eXe Learning media}

The results of the validity test from several experts stated that the eXe Learning media was valid and feasible to be used as a reaction rate learning medium, and the validity of this media was determined from several aspects including design aspects, pedagogical aspects, content aspects and usage aspects [26]. In another study [27] explicitly stated that the eXe Learning media developed was feasible to use, and this was based on student response questionnaires that responded to aspects of usefulness, aspects of ease of learning mathematics with linear programming topics, and aspects of satisfaction. In Costa Rica, research related to eXe Learning media also recommends the incumbent to use eXe Learning media as a distance and independent learning medium for high school students in statistical material. This indicates that the eXe Learning media is feasible to be used as a statistical learning media, by obtaining the results of student responses and the theoretical references used [14].

Bulegon et al. [17], recommends eXe Learning media for teachers in developing ICT-based learning, student responses to the use of eXe Learning media in physics learning include students being very happy and motivated in learning, easy understanding of the material provided and able to improve students' critical thinking processes. This proves that eXe Learning media is feasible to be used as a learning media as well as a teacher's tool in developing learning models for students. Currently, students are required to be able to apply accepted learning materials in the form of laws or formulas into real life, for example in learning physics and mathematics in the form of content derivatives from formulas and understanding the shape of a square movement, then eXe Learning media has the potential and is feasible to use. create content for physics and mathematics learning activities by including animations, simulations, images, formulas or virtual environment authoring and can be exported to other platforms such as Moodle [16].

In another study [30] made a comparison for learning mathematics mobile learning through two different applications, namely eXe Learning and MIT Invertor, and from the results of the validation or feasibility study, experts showed that the level of validation or feasibility of mobile learning mathematics applications in terms of material and appearance aspects. The screen shows the results of the validity of the eXe Learning media being higher than the MIT inverter media. This proves that eXe Learning media is very feasible to be developed into a mobile learning model, which makes it easier for students to be able to learn anytime and anywhere according to student needs in the digitalization era. The same research related to mobile learning in mathematics learning with the sub-topic of arithmetic [31] shows that eXe Learning media is very feasible to be used and applied to Android, this is based on the results of analysis of student responses from aspects of usability, ease of use, ease of learning and satisfaction. students with a fairly high score after being tested in the field.

In general, the feasibility of a learning media is determined by several aspects, including content aspects, presentation aspects, linguistic aspects, overall display aspects and several other aspects according to the needs of the media development. These aspects are considered and judged appropriate by experts, material experts, media experts and practitioners [41]. In research [26] construct validity is only seen from the design aspect, pedagogy aspect and content aspect, but it has not been explained how the review is from the language aspect and whether the language used is easily understood by students, while in the study [27] only explains the overall appearance aspect, and it does not mention other aspects, nor does it mention the choice of type and capacity of android like what can include eXe Learning media applications as mobile learning media in reaction rate learning. The capacity and ability of a tool such as android has limited capacity depending on the type and type, and it will be difficult for students who do not have android to be able to make eXe Learning in mobile learning. The same thing is also in research [30] the use of android must be reconsidered with aspects of the capacity and ability of android to be integrated with eXe Learning media. Research [14] explains from various aspects, including aspects of appearance, language aspects and content aspects, and in detail displays its strengths and weaknesses, it is further said that multimedia learning using eXe Learning media makes students interested in knowing the material, opening up students' thinking insights, foster a love and enthusiasm for learning and of course the hope to get good results, but it is not explained in detail what things make this student's strength appear and what instrument is used as a determining factor for the student's strength. The instrument used in determining the strengths and advantages of eXe Learning 
media is related to the factors of student interest, and the ease and curiosity that arises is explained in the study [31] using a student response questionnaire, meaning that it is important for research on the development of learning media by applying the design results. Learning media that have been validated and assessed by experts is carried out on a small or large scale, so it can be said that the media is suitable for use as learning media. The feasibility of eXe Learning media is also reaffirmed by research [16] [17], learning difficult and abstract material for students can use eXe Learning as a digital medium that is able to make abstract material close to the real situation that is easy for students to understand by contextualizing, observing, reflection, synthesis and can combine the material to be studied by combining interdisciplinary concepts, which will make the learning more meaningful and able to develop students' critical thinking attitude.

\section{B. Educational Level of using eXe Learning media}

Various studies conducted related to the use of eXe Learning media as ICT-based learning media (Information and Telecommunications Technology) provide an overview to teachers, lecturers and academics that this media can be used for all levels of education both at the junior high school, high school up to college level, to help students to facilitate understanding of difficult and abstract learning materials and to motivate them to like these materials, increase the enthusiasm for learning because eXe Learning media contains content that is varied with animation, video, web, digital games and others, as well as being able to improve students' critical thinking.

The eXe Learning media is used as a mathematics mobile learning for students of SMP Salatiga [30] and SMP Muhamadiyah Tepus Indonesia [31], by integrating the eXe Learning media application into Android. It is important for teachers to develop web-based teaching materials on mathematics material through mobile learning applications using eXe Learning media for students of SMA Negeri 1 Pundong and SMK Multimedia Bulu pesantren Indonesia [27].

The same thing was also done by researchers [14] who recommended eXe Learning as a distance learning media for high school students in Costa Rica in learning statistics due to time constraints, some students still have to work to meet their economic needs, even though it is through new regulations. Statistics lessons are one of the requirements for subjects in the national exam as a requirement for student graduation. The use of the eXe Learning is also recommended for teachers at Rio Grande do Sul State Senior High Schools to develop physics learning through eXe Learning media [17]. At HKBP Nomensen Pematang Siantar University revealed that the concept of an abstract chemical reaction rate can be done by visualizing it using the eXe Learning media in order to be able to achieve conceptual understanding; this is in line with research [26] for students.

\section{Effectiveness of eXe Learning media}

One of the learning strategies that are often developed by teachers is to develop learning media that are in accordance with the characteristics of student learning. This is in accordance with what was stated by [41] that there is an interaction between the use of learning media and the characteristics of students in determining learning outcomes.

The eXe Learning media can be said to be effective if this media can be used as a learning medium after the media is developed and perfected. This is in line with [41], stating that a learning media is said to be effective if the media has gone through a formative and summative evaluation process.

Improved student learning outcomes in the reaction rate material at $80 \%$ through the use of eXe Learning media compared to students using power point media only getting a score of $60 \%$ [26], the feasibility level of using eXe Learning media and student responses in a score of $72 \%-78 \%$ for several aspects of student responses, including the use of media, ease of use, ease of learning and student satisfaction in learning mathematics with linear programming [27] indicate that eXe Learning media is effectively used as a learning medium that can be developed by teachers.

The contribution of eXe Learning media in statistical learning is to help students in rural areas of Costa Rica to complete their daily tasks so that they are efficient and on time, as a distance learning medium, manage time according to students' abilities, facilitate students' understanding in taking the national statistics exam and foster motivation and critical thinking students [14] are able to provide recommendations to policymakers in the country to provide opportunities for students to study statistics using eXe Learning media. This is in line with what is stated by [41] which states that the summative evaluation of the effectiveness of learning media is carried out after the learning media is developed and can be used for the benefit of outside parties or decision makers such as funders and testers of development research. [17] succeeded in developing eXe Learning media that have been evaluated and validated to be used as references to teachers and disseminate material through the development of eXe Learning media, with the aim of motivating teachers to be able to adapt their teaching methods to the current conditions of student development, because eXe media learning is feasible and effective to be used as a learning medium.

The effectiveness of eXe Learning media is also shown in research [16] where the difficulty of students learning material that is abstract and difficult to understand, especially about laws and formulas in physics and chemistry, can be overcome by developing eXe Learning media that combines graphics through geogebra models through eXe media learning, and this is very effective in helping students to be 
able to apply this difficult material to real life. Mobile learning mathematics media developed using eXe Learning media is also very effective in student learning, where the increase in student learning outcomes before and after using eXe Learning media is quite significant with a high score category of $86.25 \%$ [30].

The same thing is also confirmed by research [31] that the increase in student learning outcomes increases significantly in learning using mobile learning based on eXe Learning on arithmetic material for learning outside of school.

\section{Use of eXe Learning media}

In line with the progress and development of science and technology, especially information and telecommunications technology (ICT), and with the increasing demands of society in the world of education, it makes ICT facilities to be developed as a medium in the learning process. In addition to traditional teaching is no longer desired by the public and students in accordance with the demands in the era of globalization. These are the reasons of using ICT-based learning media [41]. The eXe Learning media has potential benefits in solving learning problems, as conveyed from the studies above as follows:

a. Minimize the use of data bandwidth in the learning process because this media can be used offline, so eXe Learning media is very suitable for teachers who want to develop digital-based learning media, without having to use the internet, because during the Covid-19pandemic which has an impact on the decline in the economic sector in all areas business sector, also has an impact on the income of parents of students. Although in Indonesia, the government provides free internet data quota assistance for all students; of course it is not enough for student learning using digital and web content. This of course must also be supported by internet networks available in each area, so that eXe Learning media is an alternative media to be used as a student learning medium because eXe Learning media can be used without having an internet network (offline).

b. Assist teachers in utilizing information and communication technology as a learning aid. Teachers in the era of the COVID-19pandemic, of course, not many are accustomed to using information and communication technology to create learning media. However, with eXe Learning, it is easier for teachers to create technology-based learning media, because eXe Learning is an open source web or free application and in its manufacture, teachers do not have to require special skills in writing HTML, XML programming languages, or web development application programs.

c. Make it easier for students from the cognitive side to more quickly understand material that is abstract and difficult to understand. To facilitate understanding of difficult and abstract material, especially in the era of the Covid19pandemic that uses online learning through eXe Learning media, this can be done by creating iDevice content using the Virtual Environments Author concept, namely entering animated content, videos, images, formulas and graphics. d. Increase students' motivation and critical thinking level. The use of animated content, videos, pictures, formulas and graphics will make students more interactive and able to improve students' critical thinking attitudes in learning using eXe Learning media.

e. Make independent learning media for students outside of school. eXe Learning media in addition to using computers and laptops, can also be used as a mobile learning media that is easy to carry anywhere and anytime for student learning outside of school, this is in line with the era of the industrial revolution 4.0 and the era of the Covid19pandemic where the average student is a millennial generation who is familiar with the use of electronic and digital media, so that they are able to make students able to study independently.

f. Improve student learning outcomes. Learning outcomes are a measure of success in a learning process, because through learning outcomes a teacher is able to assess whether his students have succeeded in achieving the learning objectives that have been made in learning competencies. To find out student learning outcomes in eXe Learning media, tests or exams can be carried out before and after learning through setting the content of creating questions through the iDevice menu by creating a new page. Developers or teachers can create new modules through content in the iDevice by adjusting the developer's needs, for example is the content for practice questions and selfexams. Teachers can easily create questions and exercises through eXe Learning media and the assessments of student learning outcomes can also be obtained quickly. In addition to creating new pages through content in iDevice, the eXe Learning media can also provide practice questions and exams to students by integrating other web applications such as Edmodo, kahoots and others. This is very interesting for students who are familiar with the use of digital applications in this era of industrial revolution 4.0 and the era of the Covid-19 pandemic.

\section{$E$. The eXe Learning media for learning that involves three levels of chemical phenomena.}

Chemistry learning, which involves three levels of chemical phenomena, becomes a challenge for chemistry teachers in implementing learning strategies. The difficulties experienced by students in transforming the three levels of chemical phenomena are due to the fact that students are not familiar with and trained to use learning methods to represent the three levels of chemical phenomena, and students tend to represent only verbally and symbolically [42]. Several previous studies have explained how to improve students' understanding in chemistry learning that involves three levels of chemical phenomena, especially abstract chemical materials such as atomic models, atomic structures, and chemical bonds. Through the eXe Learning, students are assisted and directed using visualizations, animations, videos, discussions, interviews, and using representational modes in the teaching and learning process [43] [44] [45] [46]. 
However, another study [47] also explained that the process of forming a mental model in understanding the concept of chemistry learning involving three levels of chemical phenomena in the Covid-19 pandemic era encountered several obstacles, including economic factors, inadequate network infrastructure, lack of teacher readiness in compiling learning materials, as well as the lack of explanations from teachers. This results in a low level of student understanding in understanding chemistry learning. Therefore, through the literature review in this study, researchers encourage teachers and lecturers to understand how to use eXe Learning as a learning medium, so that difficulties -Difficulties in learning chemistry involving three levels of chemical phenomena can be minimized by integrating learning involving three levels of chemical phenomena into eXe Learning media.

The eXe Learning can facilitate and prepare abstract chemistry learning content, by displaying images, animations, videos, discussions, interviews, through the use of an instructional panel device or iDevice. In addition, eXe Learning can be used without having an internet network (offline). Based on the literature review that we have presented above that eXe Learning media is feasible, effective, can be used for various levels of education, and is an ICT-based learning media that is easily accessible, and has flexible features and menus for preparing learning content, the researcher believes that the concept of chemistry learning that involves three levels of chemical phenomena can be done by integrating the representation mode into the eXe Learning media. Furthermore, the researcher suggests that for further research it can be carried out making use multiple representation learning models to build students' mental models in chemistry [42] learning involving three levels of chemical phenomena, using eXe Learning media.

\section{F. The Role of teachers in utilizing learning media based on information and communication technology (ICT)}

The condition of the COVID-19pandemic has changed the face of the world of education not only in Indonesia but also throughout the world. This change is indeed difficult and certainly very uncomfortable, but teachers as educators must be able to change old ways of learning to new ways of learning. The condition of the Covid-19 pandemic, in almost all schools in various countries, enforce and make regulations on online learning (on the network), of course, many schools and teachers are not familiar with learning like this and it will be very difficult for them. Digital learning using internet media requires the teacher's role to design and develop online learning media by providing teaching materials through videos, animated presentation slides, textbooks, by utilizing the right online media tools according to the teacher's needs in providing material to students. Teachers must be able to choose and limit learning media according to their abilities and needs in carrying out development, of course also thinking about the economic conditions of students' parents during the Covid-19pandemic. Overall, digital online learning media certainly requires an adequate internet network, the need for data usage for online learning, and the availability of equipment that supports digital learning activities. In this literature study, we provide an alternative for teachers to learn to develop eXe Learning digital learning media with all its advantages and disadvantages.

Overall, digital online learning media certainly requires an adequate internet network, the need for data usage for online learning, and the availability of equipment that supports digital learning activities. In this literature study, we provide an alternative for teachers to learn to develop eXe Learning digital learning media with all its advantages and disadvantages.

The development of learning media is one of the factors that determine the success of learning. Through the media, the teaching and learning process can be more interesting and fun. The development of learning media is the actualization of the ability of teachers in the use of technology and media [38]. The main reason for the need to develop learning media is because of the limited learning media available for classroom learning, causing teachers to still tend to teach material using the lecture method. The development of learning media must be adapted to the needs of students and teachers in the classroom in order to increase student learning outcomes effectively. In addition, the learning media developed must also be able to support the teaching and learning process that can motivate students so as to create interaction in the classroom between students and teachers.

\section{CONCLUSION}

From the results of the literature review, it can be concluded as follows:

1. Media eXe Learning can facilitate and prepare the learning content chemistry that involves three levels of chemical phenomena (macroscopic, submicroscopic, and symbolic), by displaying descriptions, images, animations, video, questions, tasks, discussions, and interviews, through the use of panels of instructional device or iDevice. The eXe Learning media can also be integrated with chemistry learning models to build students' understanding chemistry concepts.

2. Media eXe Learning is easy and practical to manufacture and use as chemistry learning media because it does not require special knowledge and expertise. This information and communication technology-based media were created to make it easier for chemistry teachers and lecturers to develop learning strategies in the era of the Covid-19 pandemic.

\section{SUGGESTION}

The researcher recommends to all parties, especially for further researchers, to be able to use eXe Learning media to 
develop students' mental models in chemistry learning involving three levels of chemical phenomena, especially on abstract chemical materials, through multiple representation learning models that are integrated with eXe Learning media.

\section{References}

[1] OECD. (2018). Transformative Technologies and Jobs of the Future. https://www.oecd.org/sti/inno/transformativetechnologies-and-jobs-of-the-future.pdf.

[2] Zimmer, W. K., \& Mctigue, E. M. (2011). Development and validation of the teachers' digital learning identity survey. Heterocyclic Communications, 12(2). https://doi.org/10.1515/hc.2006.12.2.84.

[3] Oyedotun, T. D. (2020). Sudden change of pedagogy in education driven by COVID-19: Perspectives and evaluation from a developing country. Research in Globalization, 2(November), 100029. https://doi.org/10.1016/j.resglo.2020.100029.

[4] Lapitan, L. D., Tiangco, C. E., Sumalinog, D. A. G., Sabarillo, N. S., \& Diaz, J. M. (2021). An effective blended online teaching and learning strategy during the COVID-19pandemic. Education for Chemical Engineers, 35(May 2020), 116-131. https://doi.org/10.1016/j.ece.2021.01.012.

[5] Tigaa, R. A., \& Sonawane, S. L. (2020). An International Perspective: Teaching Chemistry and Engaging Students during the COVID-19Pandemic. Journal of Chemical Education, 97(9), 3318-3321. https://doi.org/10.1021/acs.jchemed.0c00554.

[6] Treagust, D., Nieswandt, M., \& Duit, R. (2018). Sources of students difficulties in learning Chemistry. Educación Química, 11(2), 228. https://doi.org/10.22201/fq.18708404e.2000.2.66458.

[7] Ackermans, K., Rusman, E., Brand-Gruwel, S., \& Specht, M. (2019). Solving instructional design dilemmas to develop a Video Enhanced Rubric with modeling examples to support mental model development of complex skills: the Viewbrics-project use case. Educational Technology Research and Development, 67(4), 983-1002. https://doi.org/10.1007/s11423-019-09668-1.

[8] Chittleborough, Gail and Treagust, D. F. (2004). The Role Of Teaching Models And Chemical Representation In Developing Mental Models Of Chemical Phenomena. 2007, Interrelationships between Innovation and Market Orientation in SMEs, Management Research News, Vol. 30, No. 12, Pp. 878-891., 30(12), 878-891.

[9] Journal, T., \& Impact, B. (2012). Two Ideas of the Redox Reaction: Misconceptions and their Challenge in Chemistry Education. African Journal of Chemical Education, 2(2), 32-50-50. https://doi.org/10.9790/738805111520 .

[10] Williamson, B., Eynon, R., \& Potter, J. (2020). Pandemic politics, pedagogies and practices: digital technologies and distance education during the coronavirus emergency. Learning, Media and Technology, 45(2),
$107-114$.

https://doi.org/10.1080/17439884.2020.1761641.

[11]Celik, D., \& Magoulas, G. D. (2016). Advances in WebBased Learning - ICWL 2016. 10013, 1-11. https://doi.org/10.1007/978-3-319-47440-3.

[12] Guamán Ortega, D. R. (2020). Actividades interactivas eXelearning web 3.0 para optimizar la enseñanza aprendizaje de la escritura del idioma Inglés. 524, 1-62. http://repositorio.uisrael.edu.ec/handle/47000/2564.

[13] Postgrados, E. D. E. (2018). Inés Lorena Veloz Vargas. 524.

[14] Navarro, F., \& Climent, B. (2009). eXelearning o cómo crear recursos educativos digitales con sencillez. @Tic. Revista D'Innovació Educativa, 3(3), 133-136. https://www.redalyc.org/pdf/3495/349532299021.pdf.

[15]Vidal, F. M., Gómez, E. H., Juan, I. E. S., Elcano, S., \& Hespérides, C. (2000). La herramienta de autor eXeLearning para la mejora del éxito escolar y la atención a la diversidad. 1-6.

[16] Mussoi, E. M., Flores, M. L. P., Bulegon, A. M., \& Tarouco, L. M. R. (2011). Geo Gebra and eXe Learning : applicability in the teac hing of Physics and Mathematics. Systemics, Cybernetics And Informatics.

[17]Bulegon, A. M. (2015). Objetos De Aprendizagem, EXe Learning E Moodle: Recursos Auxiliares Para O Desenvolvimento Do Pensamento Crítico No Para O Desenvolvimento Do Pensamento Crítico No Ensino Médio Learning Objects, and Learning Exe Moodle: Auxiliary Resources for Develop. 34(1), 149-172. https://doi.org/10.13140/RG.2.1.4325.8726.

[18] Moreno Hernández, M., López Felipe, Y., \& Fernández Pérez, J. A. (2021). Bases metodológicas para una práctica de campo integradora a través del uso de ExeLearning TT - Bases metodológicas para uma prática de campo integradora através do uso do ExeLearning TT - Methodological bases for an integrative field practice using Exe. Mendive. Revista de Educación, 19(1), 137151.

http://scielo.sld.cu/scielo.php?script=sci_arttext\&pid=S1 815-76962021000100137\&lang=pt.

[19] Sandro, F., Rocca, D., \& Nucara, E. (2012). Moodle come strumenti per realizzare un ambiente generativo di apprendimento.

[20] González Santiago, E., Cano Meza, M. J., \& De la Rosa Gómez, A. (2017). Desarrollo de materiales para el fomento de la autorregulación empleando eXeLearning. Revista Electrónica En Ciencias Sociales y Humanidades Apoyadas Por Tecnologías, 6(12), 31-34.

[21]Chipia Lobo, J. (2016). Objeto de aprendizaje sobre bebidas alcohólicas, tabaco y marihuana con la utilización de eXe Learning. Eduweb, 10(2), 69-80.

[22] Cordovi, V., Benito, V., Pruna, L., Muguercia, A., \& Antúnez, J. (2018). Medisan 2018; 22(3): 257. 22(3), 257-263.

[23] Garcia, M. M., \& Anarela, A. E. N. (2020). Guia Didactica En eXe Learning Para El Aprendizaje De Matematica Alicada. November. 
[24] Ortiz, V. Y., \& Toledo, M. N. (2018). EXe Learning : Digital Resource Of A Didactic Teaching Strategy Math Learning.

[25]Dange, jagannath. (2019). Zone of Proximal Development in exe-Learning platform. International Journal of Research and Analytical Reviews.

[26] Silalahi, M. V. (2020). Development of E-Modules Based on Exe-Learning on Topics of Reaction Rate Against Student Learning Outcomes Mechanical Engineering. IJECA: International Journal of Education \& Curriculum Application, 3(2), 114-120.

[27] Prasetyani, I., Darojah, D. M., Novianti, N., \& Sulisworo, D. (2019). Developing eXeLearning application through project-based learning. Journal of Physics: $\quad$ Conference Series, 1188(1). https://doi.org/10.1088/1742-6596/1188/1/012068.

[28]Bulegon, A. M., Margarida, L., \& Tarouco, R. (2015). eXe Learning and Learning Objects : Authorized Tools For The Construction Of Digital Material For science Teaching eXe Learning And Learning Objects. April 2017.

[29] Aini, L., Siswandari, P., \& Sawiji, H. (2017). The Peculiarity of E-Learning XHTML Editor (EXE) Based on Attention, Relevance, Confidence, Satisfaction (ARCS) to Improve the Students' Learning Motivation of Vocational High School. 158(Ictte), 445-456. https://doi.org/10.2991/ictte-17.2017.61.

[30] Yunianta, T. N. H., Putri, A., \& Kusuma, D. (2019). Development and Comparison of Mathematic Mobile Learning By Using Exelearning 2.0 Program and Mit Inventor 2. Infinity Journal, 8(1), 43. https://doi.org/10.22460/infinity.v8i1.p43-56

[31] Rokhima, N., Harisna, B. L., Ningrum, I. E., \& Sulisworo, D. (2019). The eXeLearning for social arithmetics through scientific approach. Journal of Physics: $\quad$ Conference Series, 1188(1). https://doi.org/10.1088/1742-6596/1188/1/012056

[32] Israel, U. T., Gestión, M., Aprendizaje, D. E. L., \& Por, M. (2020). Universidad tecnológica israel. 189.

[33] Gilbert, J. K., \& Treagust, D. F. (2009). Multiple representation in chemicals education. In Journal of Chemical Information and Modeling (Vol. 4).

[34] Praisri, A., \& Faikhamta, C. (2020). Enhancing students' mental models of chemical equilibrium through argumentation within model-based learning. International Journal of Learning, Teaching and Educational Research, 19(7), 121-142. https://doi.org/10.26803/ijlter.19.7.7.

[35] Latipah, J., Jamilah, S. N., Sari, S. T., \& Almubarak. (2021). Analysis of student's mental model through representation chemistry textbooks based on augmented reality. Journal of Physics: Conference Series, 1760(1). https://doi.org/10.1088/1742-6596/1760/1/012050

[36] Karaçam, S., \& Bilir, V. (2021). Evaluation of mental models of prospective science teachers on chemical reactions. Journal of Pedagogical Research, 5(1), 258274. https://doi.org/10.33902/jpr.2021167800
[37] Valentine, J. C., Hedges, L. V., \& Cooper, H. M. (2017). Handbook of Research Synthesis and Meta-Analysis 2nd Edition. In The Lancet (Vol. 389, Issue 10082).

[38]Cresswell, J. W. (2012). Planning, conducting and Evaluating Quantitative and Qualitative Research.

[39]Hsieh, H. F., \& Shannon, S. E. (2005). Three approaches to qualitative content analysis. Qualitative Health Research, 15(9), 1277-1288. https://doi.org/10.1177/1049732305276687.

[40] Mohamadian, A., \& Manian, A. (2015). A systematic review of research and future research directions of the virtual business incubators. BI Management Studies.

[41] Suryani, N. (2018). Media Pembelajaran Inovatif dan Pengembangannya.

[42] Sunyono. (2011). Kajian Tentang Peran Multipel Representasi Pembelajaran Kimia dalam Pengembangan Model Mental Siswa. Prosiding Seminar Nasional Sains, 15 Januari 2011. Universitas Negeri Surabaya.

[43] Roche Allred, Z. D., \& Bretz, S. L. (2019). University chemistry students' interpretations of multiple representations of the helium atom. Chemistry Education Research and Practice, 20(2), 358-368. https://doi.org/10.1039/c8rp00296g.

[44] Muntholib, M., Ilmah, M., \& Yahmin, Y. (2020). Analysis of chemistry teachers' covalent bond conceptual understanding through diagnostic interview technique. JPEK (Jurnal Pembelajaran Kimia), 5(2), 108-115. https://doi.org/10.17977/um026v5i22020p108.

[45] Sunyono, S., \& Sudjarwo, S. (2018). Mental models of atomic structure concepts of 11th grade chemistry students. Asia-Pacific Forum on Science Learning and Teaching, 19(1).

[46] Prodjosantoso, A. K., Hertina, A. M., \& Irwanto. (2019). The misconception diagnosis on ionic and covalent bonds concepts with three tier diagnostic test. International Journal of Instruction, 12(1), 1477-1488. https://doi.org/10.29333/iji.2019.12194a.

[47] Bahasoan, A. N., Wulan Ayuandiani, Muhammad Mukhram, \& Aswar Rahmat. (2020). Effectiveness of Online Learning In Pandemic Covid-19. International Journal of Science, Technology \& Management, 1(2), 100-106. https://doi.org/10.46729/ijstm.vli2.30.

\section{Creative Commons Attribution License 4.0 (Attribution 4.0 International, CC BY 4.0)}

\author{
This article is published under the terms of the Creative \\ Commons Attribution License 4.0 \\ https://creativecommons.org/licenses/by/4.0/deed.en_US
}

